\title{
Effects of Nitrogenous
}

\section{Components of the Medium on the Carbohydrate and Nucleic Acid Content of Mycobacterium tuberculosis BCG}

\author{
By F. G. WINDER AND S. A. ROONEY \\ Department of Biochemistry and Laboratories of the \\ Medical Research Council of Ireland, Trinity College, Dublin
}

(Accepted for publication 15 June 1970)

\begin{abstract}
SUMMARY
The effects of varying the concentrations of the nitrogen sources in glycerol+asparagine, glycerol + asparagine+casein hydrolysate and glycerol +ammonium sulphate media on the composition and growth rate of $\mathrm{Myco-}$ bacterium tuberculosis BCG grown in shaken culture for various periods were investigated. The bacteria were fractionated and the soluble, alkaliextractable, hot acid-soluble and residual fractions analysed for carbohydrate, RNA, DNA, free lipid, soluble amino compounds and soluble phosphates.

The results indicate that several forms of growth restriction operated in these experiments: a progressive reduction in growth rate even in conditions when nutrients were not limiting, due to clumping of cells; a reduction in growth rate following any reduction in the amino acid content of the medium; a marked reduction in growth rate when the amino acid content of the medium fell below a critical level, or was replaced by ammonium ions. When the growth rate was reduced because of nutrient limitation, the carbohydrate content of the bacteria increased, but the pattern of accumulation varied with the experimental conditions. The RNA: protein ratio of the cells was little affected by growth rate.
\end{abstract}

\section{INTRODUCTION}

Although much is known about the chemistry of mycobacteria, including Mycobacterium tuberculosis, quantitative studies on how their composition varies with environmental conditions have been few. Until very recently, only in the case of Mycobacterium phlei had studies been made of the effects of environment on carbohydrate content (Tepper, 1965; Antoine \& Tepper, 1969a). The studies outlined in this paper were carried out primarily to obtain background information against which to interpret the effects of isoniazid on the carbohydrates of $M$. tuberculosis (Winder, Brennan \& McDonnell, I967; Winder \& Rooney, 1970). Since this work was done, Antoine \& Tepper ( $1969 b$ ) have given a short report on the environmental control of the carbohydrate and lipid content of $M$. tuberculosis RIRv, and their results are essentially in agreement with some of those in this paper.

As far as variations in DNA, RNA and soluble phosphate contents of mycobacteria are concerned, only in the case of Mycobacterium smegmatis and $M$. phle $i$ have detailed studies been made (Winder \& Denneny, I956; Winder \& O'Hara, I962; Tepper, 1965; F. G. Winder \& M. P. Coughlan, unpublished observations). Consequently, observations on the effects of environment on the amounts of these materials in $M$. tuberculosis are included in this paper. 


\section{METHODS}

Media. The glycerol + asparagine medium usually had the composition of Sauton medium, as described by Soltys (1952), except that the concentration of glycerol was $75.5 \mathrm{~g}$./1. The glycerol + asparagine + casein hydrolysate medium usually had the same composition, with the addition of $3 \mathrm{~g}$. pancreatic casein hydrolysate/1. Where required, variations in the composition of these two media are noted in the text. All of these media contained ammonium ions (about $400 \mathrm{mg}$. N/l.) in addition to the organic nitrogen. In the glycerol + ammonium sulphate media, the amino acids were replaced by ammonium sulphate, normally $8 \mathrm{~g}$. $/ 1$.

Growth of bacteria. Mycobacterium tuberculosis, var. bovis, strain BCG(Glaxo Laboratories Ltd) was grown as described previously (Winder et al. 1967) under stationary conditions for 4 days and then with shaking for further periods.

Extraction procedures. The 'soluble', 'free lipid' and 'alkali-extractable fractions' were obtained as described by Winder \& Rooney (1970), and the remaining insoluble fraction was used to obtain the 'hot acid-soluble' and 'residual' fractions in the manner described by Winder et al. (1967).

Assays. Except where otherwise stated, carbohydrates were determined by an anthrone procedure (Winder et al. 1967). The phenol method was that of Dubois et al. (1956). In both cases the results are given in terms of glucose as the standard. 'Combined phosphate' is the difference between total phosphate and inorganic phosphate, which were determined as described by Winder \& O'Hara (I962), as were total nitrogen (determined in the insoluble fraction), RNA and DNA. Amino acids were determined by the method of Moore \& Stein (1954), using leucine as the standard.

The organic nitrogen content of the medium at the time of harvesting was estimated by subtracting the insoluble nitrogen content of the bacteria from the initial organic nitrogen content of the medium.

\section{RESULTS}

The effects of age on the composition of bacteria from relatively young batch cultures of Mycobacterium tuberculosis BCG grown in our normal glycerol + asparagine + casein hydrolysate medium are shown in Tables I and 2. The data on yields in the tables showed that, although the cultures were young and far from exhaustion of any component in the medium, growth was not truly exponential: the generation time increased from rather less than $24 \mathrm{~h}$. to rather more than $48 \mathrm{~h}$. over the 6 days of the experiment. These cultures showed a small increase in total carbohydrate content per unit of nitrogen with age over the period studied; this increase was due to an upward tendency in the soluble and alkali-extractable fractions partly balanced by a downwards tendency in the carbohydrate content of the residue. There was no trend in the RNA content per unit of nitrogen of such cultures, but there were marked upward trends in the DNA and lipid contents and perhaps in the content of soluble amino compounds, and a marked downward trend in their soluble combined phosphate content.

When the casein hydrolysate was omitted from the medium, the cultures of $\mathrm{Myco}$ bacterium tuberculosis BCG grew more slowly (Tables I and 2, Expt. b). Their carbohydrate content at low yields was higher than in the richer medium, largely due to a much higher content of hot acid-soluble carbohydrate. The carbohydrate content of 
Table I. Effect of age of culture and medium constituents on the carbohydrate composition of Mycobacterium tuberculosis BCG

All the media contained glycerol together with $(a) 4 \mathrm{~g}$. asparagine $+3 \mathrm{~g}$. casein hydrolysate/l., (b) 4 g. asparagine/l. and (c) reduced asparagine + casein hydrolysate (respectively I g. + $0.75 \mathrm{~g} / \mathrm{l}$.). Data in $(a),(b)$ and $(c)$ from different experiments. Results are expressed per $\mathrm{g}$. insoluble nitrogen.

Carbohydrate fractions

\begin{tabular}{|c|c|c|c|c|c|c|c|}
\hline Age & $\begin{array}{l}\text { Yield of cells } \\
\text { (mg. insoluble }\end{array}$ & $\begin{array}{l}\text { Organic nitrogen } \\
\text { in medium }\end{array}$ & Soluble & $\begin{array}{c}\text { Alkali- } \\
\text { extractable }\end{array}$ & $\begin{array}{l}\text { Hot acid- } \\
\text { soluble }\end{array}$ & Residue & $\begin{array}{c}\text { Total carbo- } \\
\text { hydrate }\end{array}$ \\
\hline (days) & $\mathrm{N} / 1)$. & (mg. N/I.) & & & amoles 'glu & & \\
\hline
\end{tabular}

(a) Medium with $4 \mathrm{~g}$. asparagine $+3 \mathrm{~g}$. casein hydrolysate $/ 1$.

\begin{tabular}{|c|c|c|c|c|c|c|c|}
\hline 6 & 7.9 & 1310 & $2 \cdot 67$ & I.9I & $2 \cdot 39$ & $2 \cdot 28$ & $9 \cdot 24$ \\
\hline 7 & $17 \cdot 1$ & 1300 & $2 \cdot 74$ & $2 \cdot 14$ & $2 \cdot 64$ & 2.45 & 9.96 \\
\hline 8 & $32 \cdot 0$ & I 290 & $3 \cdot 20$ & $2 \cdot 0 \mathrm{I}$ & $2 \cdot 87$ & $2 \cdot 35$ & 10.42 \\
\hline 9 & $5 \mathrm{I} \cdot 3$ & I 270 & 3.64 & $2 \cdot 36$ & $2 \cdot 3 \mathrm{I}$ & $2 \cdot 19$ & 10.50 \\
\hline IO & $72 \cdot 5$ & 1250 & $3 \cdot 43$ & $2 \cdot 26$ & $2 \cdot 67$ & $2 \cdot 13$ & 10.49 \\
\hline I 2 & $135^{\circ} 2$ & 1180 & 3.43 & 3.03 & $2 \cdot 15$ & $\mathrm{I} \cdot 57$ & $10 \cdot 17$ \\
\hline
\end{tabular}

(b) Medium with $4 \mathrm{~g}$. asparagine/1.

\begin{tabular}{|c|c|c|c|c|c|c|c|}
\hline 9 & $4 \cdot 3$ & 840 & $2 \cdot 35$ & 2.62 & 10.10 & $2 \cdot 86$ & $17 \cdot 93$ \\
\hline I I & 15.4 & 825 & - & - & - & - & I 6.63 \\
\hline $13^{*}$ & $42 \cdot 2$ & 798 & $2 \cdot 4^{8}$ & $3 \cdot 20$ & $8 \cdot 2 \mathrm{I}$ & $2 \cdot 37$ & $16 \cdot 26$ \\
\hline $15^{*}$ & $55 \cdot 8$ & 784 & 3.52 & $2 \cdot 56$ & $6 \cdot 55$ & $\mathrm{I} \cdot 74$ & $14 \cdot 37$ \\
\hline
\end{tabular}

(c) Medium with I g. asparagine $+0.75 \mathrm{~g}$. casein hydrolysate/l.

\begin{tabular}{|c|c|c|c|c|c|c|}
\hline $8 *$ & $32 \cdot 5$ & 297 & $3 \cdot 18$ & $2 \cdot 29$ & $9 \cdot 65$ & 3.71 \\
\hline $12 *$ & $141 \cdot 5$ & I 88 & $3 \cdot 29$ & $4 \cdot 27$ & $11 \cdot 56$ & $6 \cdot 73$ \\
\hline $17 \%$ & $318 \cdot 0$ & 12 & $8 \cdot 82$ & 9.03 & 26.06 & 5.87 \\
\hline $20 \dagger$ & $354^{\circ} \mathrm{O}$ & - & $7 \cdot 84$ & $1 \mathrm{I} \cdot 03$ & $27 \cdot 52$ & $8 \cdot 76$ \\
\hline
\end{tabular}

* Mean values from two experiments. $†$ Mean values from four experiments.

Table 2. Effect of age of culture and medium constituents on the phosphorus components, amino compounds and lipids of Mycobacterium tuberculosis BCG

Data in $(a)$ and $(b)$ refer respectively to same experiments as $(a)$ and $(b)$ in Table I. Results are expressed per $\mathrm{g}$. insoluble nitrogen.

\begin{tabular}{|c|c|c|c|c|c|c|}
\hline & & Soluble fraction & & & & \\
\hline $\begin{array}{l}\text { Age } \\
\text { (days) }\end{array}$ & $\begin{array}{l}\text { Nucleotides } \\
\text { (as } \mu \text { moles } \\
\text { AMP) }\end{array}$ & $\begin{array}{l}\text { Amino compounds } \\
\text { (as } \mu \text { moles } \\
\text { leucine) }\end{array}$ & $\begin{array}{c}\text { Combined } \\
\text { phosphate } \\
(\mu \mathrm{g} . \text { atoms } \mathrm{P})\end{array}$ & $\begin{array}{c}\text { RNA } \\
(\mu \mathrm{g} . \text { atoms } \mathbf{P})\end{array}$ & $\begin{array}{c}\text { DNA } \\
(\mu \mathrm{g} . \text { atoms } \mathrm{P})\end{array}$ & $\begin{array}{l}\text { Lipids } \\
\text { (g.) }\end{array}$ \\
\hline
\end{tabular}

(a) Medium with $4 \mathrm{~g}$. asparagine $+3 \mathrm{~g}$. casein hydrolysate/l.

\begin{tabular}{|c|c|c|c|c|c|}
\hline 6 & 220 & I I 40 & 1650 & I 350 & 670 \\
\hline 7 & 235 & 1230 & 986 & I 440 & 783 \\
\hline 8 & 225 & 1090 & 900 & 1290 & 716 \\
\hline 9 & 234 & 1750 & 976 & 1460 & 784 \\
\hline Io & 204 & 1270 & 728 & I3IO & 857 \\
\hline I 2 & 208 & 2670 & 483 & I 450 & 1460 \\
\hline \multicolumn{6}{|c|}{ (b) Medium with $4 \mathrm{~g}$. asparagine/1. } \\
\hline 9 & 466 & 1610 & I 210 & I 340 & 935 \\
\hline I I & 495 & 3210 & 1097 & 1300 & 1030 \\
\hline $13^{*}$ & 299 & 6450 & I054 & 1260 & 1013 \\
\hline
\end{tabular}

* Mean values from two experiments. 
this fraction and of the residue decreased with age, leading, in spite of an increase in the combined soluble and alkali-extractable fractions, to a smaller total carbohydrate content. The content of soluble amino compounds increased markedly with age. Initially the bacteria had higher DNA, soluble nucleotide and lipid contents per unit of nitrogen than the bacteria from the richer medium.

Cultures were also grown in a medium containing only one-quarter of the normal concentration of asparagine and casein hydrolysate (Table I, Expt. c), so that the initial concentration of amino acid nitrogen in the medium was only $330 \mathrm{mg}$. $/ 1$; this fell to below $200 \mathrm{mg}$./1. after I 2 days and practically to zero after 17 days. Such

Table 3. Effect of concentration of asparagine + casein hydrolysate in the glycerol + asparagine + casein hydrolysate medium on the carbohydrate composition of Mycobacterium tuberculosis $B C G$

Bacteria harvested after (a) 9 days growth and $(b)$ I4 days growth. $(a)$ and $(b)$ are different experiments. Results expressed per $\mathrm{g}$. insoluble nitrogen.

\begin{tabular}{|c|c|c|c|c|c|c|c|c|}
\hline \multicolumn{2}{|c|}{ Me dium composition } & \multirow[b]{2}{*}{$\begin{array}{l}\text { Yield of } \\
\text { cells } \\
\text { (mg. insoluble } \\
\text { N/l.) }\end{array}$} & \multirow[b]{2}{*}{$\begin{array}{l}\text { Organic } \mathrm{N} \\
\text { in medium } \\
(\mathrm{mg} . \mathrm{N} / \mathrm{l} .)\end{array}$} & \multicolumn{5}{|c|}{ Carbohydrate fractions } \\
\hline $\begin{array}{l}\text { Asparagine } \\
\text { (g./l.) }\end{array}$ & $\begin{array}{c}\text { Casein } \\
\text { hydrolysate } \\
\text { (g./l.) }\end{array}$ & & & Soluble & $\begin{array}{l}\text { Alkali- } \\
\text { extractable }\end{array}$ & $\begin{array}{l}\text { Hot acid- } \\
\text { soluble } \\
\text { mmoles 'g }\end{array}$ & $\begin{array}{l}\text { Residue } \\
\text { ucose') }\end{array}$ & $\begin{array}{c}\text { Total } \\
\text { carbohydra }\end{array}$ \\
\hline & & & & (a) & & & & \\
\hline 8 & 6 & $43 \cdot 0$ & 2600 & $2 \cdot 37$ & I $\cdot 54$ & 2.06 & 0.922 & 6.89 \\
\hline 4 & 3 & $39^{\circ} 0$ & I 280 & $3 \cdot 26$ & $2 \cdot 28$ & $3 \cdot 36$ & $1 \cdot 90$ & $10 \cdot 74$ \\
\hline 2 & $1 \cdot 5$ & 28.0 & 630 & 3.06 & $\mathrm{I} \cdot 93$ & 3.81 & $2 \cdot 38$ & I I $\cdot 18$ \\
\hline I & 0.75 & $25 \cdot 0$ & 305 & $3 \cdot 16$ & $1 \cdot 83$ & $5 \cdot 25$ & $3 \cdot 73$ & I 3.97 \\
\hline & & & & (b) & & & & \\
\hline 8 & 6 & 250 & 2390 & $\mathrm{I} \cdot 55$ & $2 \cdot 30$ & 2.09 & 0.593 & $6 \cdot 54$ \\
\hline 4 & 3 & 250 & 1070 & $\mathrm{I} \cdot 98$ & 3.07 & $2 \cdot 38$ & 0.918 & $8 \cdot 34$ \\
\hline 2 & $1 \cdot 5$ & 204 & 456 & $3 \cdot 20$ & 4.07 & 5.43 & $3 \cdot 12$ & 15.82 \\
\hline $\mathbf{I}$ & $0 \cdot 75$ & 177 & I 53 & 4.08 & 3.69 & 8.07 & $5 \cdot 23$ & $21 \cdot 07$ \\
\hline 0.5 & 0.375 & $33 \cdot 8$ & I3I & $6 \cdot 45$ & $5 \cdot 98$ & 10.32 & $5^{\circ} 03$ & $28 \cdot 04$ \\
\hline
\end{tabular}

Table 4. Effect of concentration of asparagine + casein hydrolysate in the glycerol + asparagine + casein hydrolysate medium on the phosphorus components, amino compounds and lipids of Mycobacterium tuberculosis BCG

Expts $(a)$ and $(b)$ are the same as $(a)$ and $(b)$ in Table 3. Results are expressed per g. insoluble nitrogen.

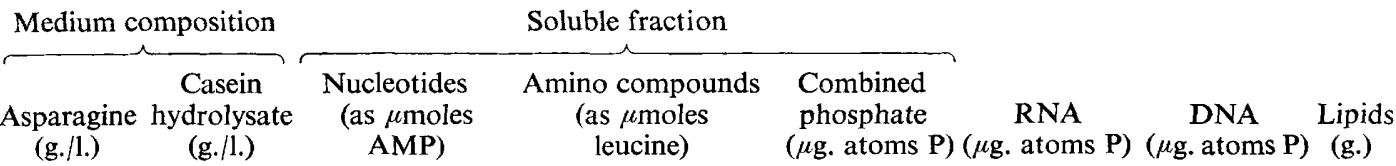

\begin{tabular}{|c|c|c|c|c|c|c|c|}
\hline \multicolumn{8}{|c|}{ (a) } \\
\hline 8 & 6 & 210 & - & I 200 & 1300 & 608 & - \\
\hline 4 & 3 & 259 & - & 1350 & I 620 & 750 & $\cdots$ \\
\hline 2 & $1 \cdot 5$ & 267 & - & 1410 & 1280 & 663 & - \\
\hline I & 0.75 & 259 & - & 1470 & 1070 & 568 & $\cdots$ \\
\hline \multicolumn{8}{|c|}{ (b) } \\
\hline 8 & 6 & 139 & 2340 & 533 & 1020 & 764 & $4 \cdot 25$ \\
\hline 4 & 3 & $16 I$ & 2500 & 610 & 1250 & $68 I$ & 4.58 \\
\hline 2 & $I \cdot 5$ & 216 & I 120 & 890 & I 440 & 785 & 4.52 \\
\hline I & 0.75 & 255 & 890 & II 30 & I I 50 & 570 & - \\
\hline
\end{tabular}


cultures grew initially more slowly than normal cultures. This can be seen from the results in Table 3 but is not apparent from those in Table I since the picture is confused by the fact that in different experiments (e.g. $a, c$ in Table I) the length of the lag period frequently varied. This slower growth was accompanied by a higher content of carbohydrate, even after 8 days, than in the richer cultures, largely due to an increase in hot acid-soluble carbohydrate and, to a smaller extent, in residual carbohydrate. As the growth rate declined after about $\mathrm{I} 2$ days, due to the falling amino acid content of the medium, the carbohydrate content of all fractions increased.

In order to confirm the effects on carbohydrate content of changing the concentrations of nitrogen sources, and to avoid complications due to interexperimental variation, cultures containing different initial concentrations of asparagine and casein hydrolysate were incubated together and all were harvested after a fixed time. Tables 3 and 4 show the results of two experiments employing different growth periods. In the early stages of growth of such cultures (e.g. up to 9 days), even though the amino acid nitrogen content of the medium in all the cultures was still more than $300 \mathrm{mg}$./., the growth rate diminished slightly but progressively with decreasing concentrations of asparagine and casein hydrolysate. Accompanying this diminished growth rate there was a marked increase in the hot acid-soluble and residual carbohydrate, while the carbohydrate content of the other two fractions remained relatively unaffected. There were no consistent changes in nucleic acid content with the nitrogen content of the medium. When the organic nitrogen content of the medium was reduced to half of the lowest concentration of $0.5 \mathrm{~g}$. asparagine and $0.375 \mathrm{~g}$. casein hydrolysate/l., growth was extremely slow and insufficient material was available for analysis after 9 days growth.

After longer incubation periods there was a tendency for the differences in growth rates to become reduced, probably due to the growth-retarding effect of the formation of cell clumps (see below) which would operate sooner in the more rapidly growing cultures. After $\mathrm{I} 4$ days growth the cultures with $2 \mathrm{~g}$. asparagine $+\mathrm{I} \cdot 5 \mathrm{~g}$. casein $/ \mathrm{l}$. showed signs of a general increase of carbohydrate content in all fractions, a decrease in soluble amino compounds and an increase in soluble combined phosphate. All of these results are characteristic of limitation of amino acids in the medium, even though there was still about $450 \mathrm{mg}$. amino acid nitrogen/l. of medium. These effects were decidedly more marked in the cultures containing I g. asparagine $+0 \cdot 75 \mathrm{~g}$. casein hydrolysate/l., in which the organic nitrogen content of the medium had fallen to $150 \mathrm{mg}$./1. after I4 days growth. Cultures which initially had a still lower concentration of amino acids in the medium grew very slowly and the accumulation of carbohydrate in all the fractions (except the residue) was more marked.

The results indicate that growth rate and carbohydrate content of the bacteria, particularly in the hot acid-soluble and residual fractions, was affected by the amino acid content of the medium within a wide range of concentrations, but that the effects became marked when the organic nitrogen content of the medium dropped below about $500 \mathrm{mg} / \mathrm{l}$., and particularly when it dropped to $200 \mathrm{mg} / \mathrm{l}$. or below.

Results in general conformity with this were obtained in glycerol + asparagine media (Tables 5,6 ). Reduction in the asparagine content of the medium in the range 16 to $4 \mathrm{~g}$./l. reduced the growth rate, though the results for the carbohydrate content of the cells were somewhat erratic. At the lower asparagine concentrations, corresponding to about 400 and $200 \mathrm{mg}$. amino acid nitrogen $/ \mathrm{l}$ much more marked changes occurred. The growth rate was strikingly reduced. The cells had a high carbohydrate content and, 
particularly at the lowest nitrogen level (I g. asparagine/1.), a low content of soluble amino compounds and some increase in soluble combined phosphate. In one respect, however, the effects of reduction in the amino acid content of the glycerol + asparagine media differed from the effects of reduction in nitrogen content of the glycerol +

Table 5. Effect of concentration of asparagine in glycerol + asparagine medium and of ammonium sulphate in glycerol + ammonium sulphate medium on the carbohydrate composition of Mycobacterium tuberculosis $B C G$

Bacteria harvested after 15 days growth. Results are expressed per g. insoluble nitrogen.

Data in $(a)$ and $(b)$ from different experiments.

\begin{tabular}{|c|c|c|c|c|c|c|c|}
\hline \multicolumn{8}{|c|}{$\mathbf{s}$} \\
\hline $\begin{array}{l}\text { Nitrogen } \\
\text { source } \\
\text { (g./l.) }\end{array}$ & $\begin{array}{c}\text { Yield } \\
\text { (mg. insoluble } \\
\mathrm{N} / \mathrm{l} .)\end{array}$ & $\begin{array}{l}\text { Organic } \mathrm{N}(a) \text { or } \\
\mathrm{NH}_{4}-\mathrm{N}(b) \text { in } \\
\text { medium } \\
(\mathrm{mg} . \mathrm{N} / 1 .)\end{array}$ & Soluble & $\begin{array}{l}\text { Alkali- } \\
\text { extractable } \\
\text { (as }\end{array}$ & $\begin{array}{l}\text { Hot acid- } \\
\text { soluble }\end{array}$ & $\begin{array}{l}\text { Residue } \\
\text { (cose') }\end{array}$ & $\begin{array}{l}\text { Total } \\
\text { carbohy- } \\
\text { drate }\end{array}$ \\
\hline \multicolumn{8}{|c|}{ (a) Asparagine } \\
\hline I6 & $104 \cdot 7$ & 3260 & 3.42 & $4 \cdot 70$ & $4 \cdot 94$ & $I \cdot 6 I$ & 14.67 \\
\hline 8 & $85 \cdot 7$ & I 590 & $3 \cdot 26$ & $4 \cdot 06$ & $8 \cdot 56$ & $2 \cdot 73$ & $\mathrm{I} 8 \cdot 6 \mathrm{I}$ \\
\hline 4 & $58 \cdot 7$ & 780 & $3 \cdot 04$ & $6 \cdot 40$ & $5 \cdot 20$ & $\mathrm{I} \cdot 95$ & 16.59 \\
\hline 2 & I I $\cdot 3$ & 409 & $2 \cdot 74$ & $3 \cdot 46$ & I $5 \cdot 35$ & $4 \cdot 10$ & $25 \cdot 65$ \\
\hline I & $\mathbf{I} \cdot 8$ & 208 & $1 \cdot 10$ & $7 \cdot 55$ & $25 \cdot 80$ & $8 \cdot 69$ & $43 \cdot 14$ \\
\hline \multicolumn{8}{|c|}{ (b) Ammonium sulphate } \\
\hline 8 & $16 \cdot 9$ & 1680 & $9 \cdot 95$ & $4 \cdot 55$ & $23 \cdot 25$ & $4 \cdot 77$ & $42 \cdot 52$ \\
\hline 2 & $17 \cdot 8$ & 407 & $7 \cdot 43$ & $4 \cdot 44$ & $23 \cdot 10$ & $5 \cdot 58$ & $40 \cdot 55$ \\
\hline
\end{tabular}

Table 6. Effect of concentration of asparagine in glycerol + asparagine medium and of ammonium sulphate in glycerol + ammonium sulphate medium on the phosphorus components, amino compounds and lipids of Mycobacterium tuberculosis BCG

Bacteria harvested after 15 days growth. Results are expressed per g. insoluble N. Expts $(a)$ and $(b)$ are the same as $(a)$ and $(b)$ in Table. 5 .

\begin{tabular}{|c|c|c|c|c|c|c|}
\hline \multirow[b]{2}{*}{$\begin{array}{l}\text { Nitrogen } \\
\text { source } \\
\text { (g./1.) }\end{array}$} & \multicolumn{3}{|c|}{ Soluble fractions } & \multirow[b]{2}{*}{$\begin{array}{c}\text { RNA } \\
(\mu \mathrm{g} . \text { atoms P) }\end{array}$} & \multirow[b]{2}{*}{$\begin{array}{c}\text { DNA } \\
(\mu \mathrm{g} . \text { atoms } \mathrm{P})\end{array}$} & \multirow[b]{2}{*}{$\begin{array}{l}\text { Lipids } \\
\text { (g.) }\end{array}$} \\
\hline & $\begin{array}{l}\text { Nucleotides } \\
\text { (as } \mu \text { moles } \\
\text { AMP) }\end{array}$ & $\begin{array}{l}\text { Amino compounds } \\
\text { (as } \mu \text { moles } \\
\text { leucine) }\end{array}$ & $\begin{array}{c}\text { Combined } \\
\text { phosphates } \\
(\mu \mathrm{g} . \text { atoms P) }\end{array}$ & & & \\
\hline \multicolumn{7}{|c|}{ (a) Asparagine } \\
\hline I6 & 230 & 7470 & 995 & I 808 & 1045 & $3 \cdot 82$ \\
\hline 8 & 227 & 7500 & - & 1509 & I I 65 & $3 \cdot 84$ \\
\hline 4 & 227 & 6850 & 1260 & 1260 & 1013 & $3 \cdot 83$ \\
\hline 2 & 258 & 1750 & 1323 & I 528 & I044 & - \\
\hline \multicolumn{7}{|c|}{ (b) Ammonium sulphate } \\
\hline 8 & 528 & 7620 & I 880 & I 559 & 1408 & $3 \cdot 67$ \\
\hline 2 & 428 & 2500 & I 670 & 17 I 5 & I 545 & - \\
\hline
\end{tabular}

asparagine + casein hydrolysate media : in the former case the reduction led to a reduced content of soluble carbohydrate in the cells, while in the latter case it led to an increase in this material.

The use of an ammonium salt as the sole nitrogen source led to slow growth and a high carbohydrate content of all fractions (Tables 5,6). It also led to a high soluble pool of nucleotides and combined phosphates, and to a rather high DNA content. 
Reducing the concentration of $\left(\mathrm{NH}_{4}\right)_{2} \mathrm{SO}_{4}$ from $1700 \mathrm{mg}$. $\mathrm{NH}_{4}-\mathrm{N} / 1$. to $400 \mathrm{mg}$. $\mathrm{NH}_{4}-\mathrm{N} / \mathrm{l}$. of medium had little effect on the composition of the cells, apart from the concentration of soluble amino compounds, which showed a substantial decrease (Tables 5,6). It should be noted, however, that the ninhydrin method, which was used to measure the amino compounds, also responds to ammonium ions, and it seems likely that it was the concentration of these which changed in response to the external ammonium ion concentration.

Table 7. Changes in the composition of Mycobacterium tuberculosis BCG, grown in glycerol + asparagine + casein hydrolysate medium and then transferred to other media for $6 h$.

Figures for insoluble nitrogen were obtained by dividing final values by initial values. Other figures were obtained by dividing final values per $\mathrm{g}$. of insoluble nitrogen by initial values per $\mathrm{g}$. of initial insoluble nitrogen. The results are the means from two experiments.

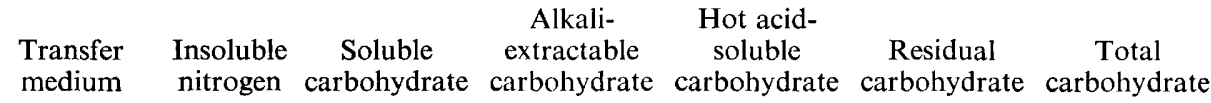

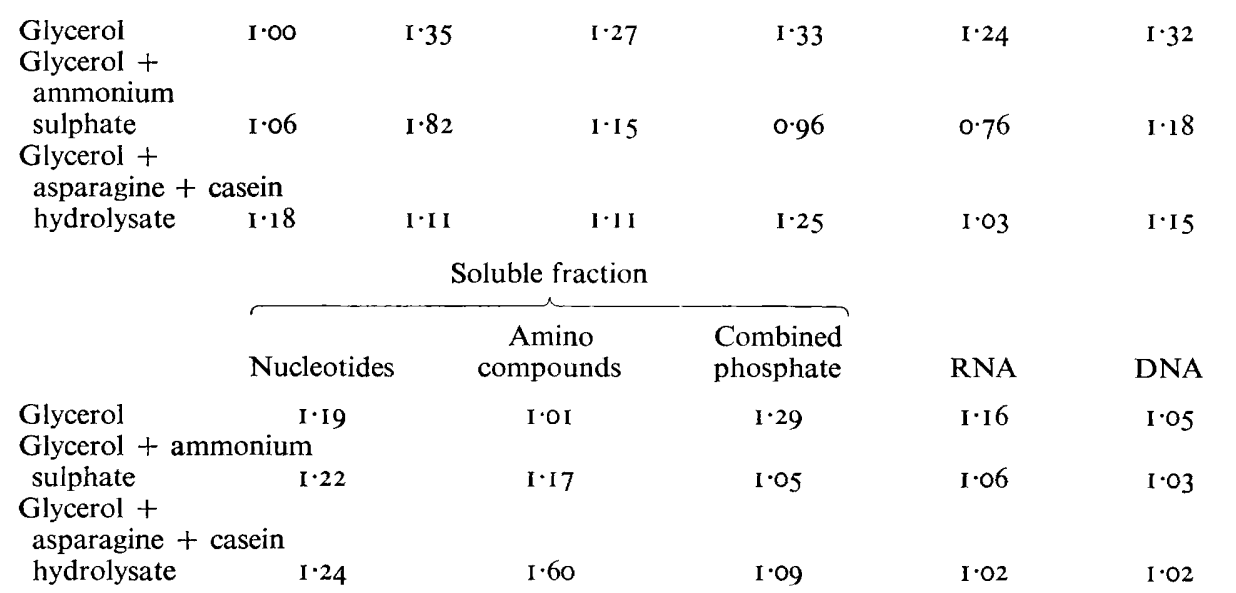

In order to study the speed with which the composition of Mycobacterium tuberculosis BCG responded to altered growth conditions, bacteria which had been grown in glycerol + asparagine + casein hydrolysate medium were washed and resuspended either in the same medium or in glycerol + ammonium sulphate medium, or in glycerol medium with no nitrogen, and incubated for $6 \mathrm{~h}$. (Table 7). As judged by total nitrogen content, organisms resuspended in the original medium resumed growth at something like the previous rate, those in the ammonium sulphate medium grew slightly, while those in the nitrogen-free medium did not change in nitrogen content. Even in the short period of the experiment, the carbohydrate per unit of nitrogen increased markedly in all the fractions obtained from the bacteria incubated in the nitrogen-free medium, while only a slight increase took place in the original medium. In the ammonium sulphate medium there was an unexpected fall in the carbohydrate content of the residue and a marked increase in the soluble fraction. An increase in soluble nucleotide content took place in all media, there was a marked increase in the soluble amino acid content in the original medium and in the soluble phosphate in the nitrogen-free medium. Other 
changes in the composition of the bacteria during the experimental period were marginal.

Since the glycerol concentration in the media employed in this work was high $(75.5 \mathrm{~g} .1 \mathrm{l}$.$) , experiments were carried out to compare the carbohydrate content of$ Mycobacterium tuberculosis BCG grown in such media with its content in media with one-tenth the amount of glycerol. The lower concentration was still sufficient to provide a substantial excess of glycerol, since the concentration in the medium had not been appreciably reduced at the time of harvesting. It was found both with asparagine +

Table 8. The effect of reducing the glycerol concentration in the medium on the carbohydrate content of Mycobacterium tuberculosis $B C G$

Carbohydrate was assayed by the phenol method. Results are the mean values from two experiments.

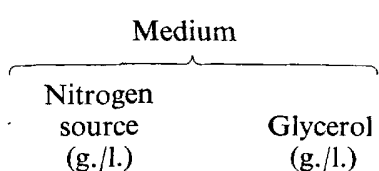

(g./l.)
Glycerol
(g./1.)

$\overbrace{\begin{array}{c}\text { Alkali- } \\ \text { Solublable }\end{array}}^{\begin{array}{c}\text { Hot acid-soluble } \\ \text { plus residue }\end{array}} \begin{gathered}\text { Total } \\ \text { carbohydrate }\end{gathered}$

(as mmoles 'glucose'/g. insoluble nitrogen)
Asparagine (4) + casein hydrolysate (3)

Ammonium sulphate (8)

$\begin{array}{ccc}75 \cdot 5 & 2 \cdot 88 & 3.56 \\ 7 \cdot 55 & 2 \cdot 78 & 2 \cdot 99 \\ 75 \cdot 5 & 6.87 & 4 \cdot 73 \\ 7 \cdot 55 & 6.61 & 4.55\end{array}$

$\begin{array}{ll}8 \cdot 15 & 14.59 \\ 5.89 & 11 \cdot 66 \\ 15 \cdot 17 & 26.80 \\ 9.65 & 20.82\end{array}$

Table 9. Carbohydrate compounds of the soluble fraction from Mycobacterium tuberculosis BCG grown with different amounts of glycerol in asparagine + casein hydrolysate medium and in ammonium sulphate medium

The fraction was concentrated, de-ionized with Amberlite MB-I, chromatographed in ethyl acetate + pyridine + water (I0:4:3, by vol.) and the bands eluted and assayed by the phenol method, all as described by Winder \& Rooney (1970). The results are given as $\mu$ moles 'glucose'/g. insoluble' nitrogen.

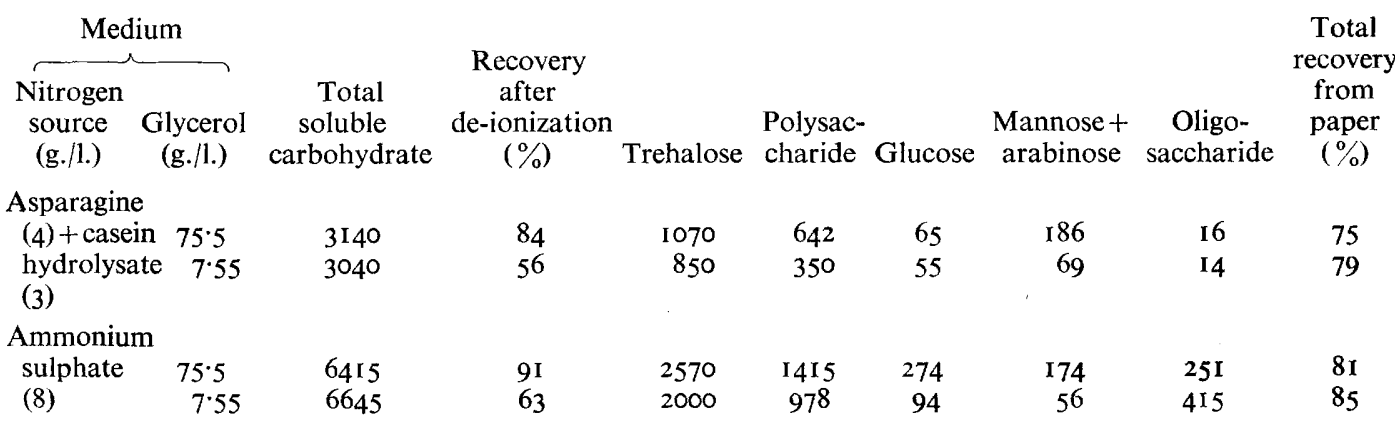

casein hydrolysate medium and ammonium sulphate medium that this reduction in glycerol concentration slightly reduced the carbohydrate content of the bacteria, the reduction taking place mainly in the insoluble fraction (Table 8). No experiments in glycerol-limited media were carried out.

In one such experiment the carbohydrates of the soluble fraction were subjected to further fractionation by paper chromatography, followed by elution and assay (Table 9). It was found that the change from the asparagine + casein hydrolysate medium 
to the ammonium sulphate medium increased the amounts of trehalose and polysaccharide in about the same proportion and also caused a large increase in the oligosaccharide content of the fraction. Reduction in the glycerol content in both media reduced the trehalose and polysaccharide content of the fraction to a greater extent than the total carboyhdrate content. It was noticed that when material from bacteria grown in the low glycerol medium was de-ionized by a mixed-bed resin treatment, the recovery of total carbohydrate was poor, suggesting that the soluble fraction of these bacteria had a high content of ionic derivatives of carbohydrates, presumably phosphorylated compounds.

\section{DISCUSSION}

The results obtained suggest that complex combinations of environmental effects operate even in the apparently simple experimental systems employed. Even in young cultures, in which all the known nutrients are far from exhaustion, the growth rate of Mycobacterium tuberculosis BCG declines progressively with age of culture. This has been observed also in shaken cultures of $M$. smegmatis when dispersing agents are not employed (F. G. Winder \& M. P. Coughlan, unpublished observations). The reduction in growth rate is probably due to growth in the form of clumps, which increase in average size during the life of the culture, and within which the ill-defined phenomenon of 'cellular crowding' may take place. Effects of crowding have been demonstrated in M. smegmatis (Maruyama, Ono \& Sato, 1963), and in Escherichia coli crowding appears to operate by leading to a shortage of energy sources which can be utilized under the redox conditions prevailing (Freter \& Ozawa, 1963): such conditions may exist within the clumps. Decline in growth rate in $M$. tuberculosis BCG under these conditions is characterized by constant carbohydrate content and an increased DNA:protein ratio.

A second form of growth rate limitation is observed when the concentration or variety of amino acids in the medium is reduced. A progressive impoverishment of the medium in this fashion leads to a progressive decline in growth rate, even though the total pool of soluble amino compounds in the bacteria is relatively constant. This decline in growth rate is accompanied by a relatively small increase in total carbohydrate, confined to the hot acid-soluble and residual fractions. It is suggested that the richness of the medium in amino acids affects the steady state concentration of a limited number of amino acids within the cell, presumably amino acids whose carbon skeleton can only be synthesized slowly from glycerol, and that this affects the rate of protein synthesis. The cellular carbohydrate is largely derived from glycerol (F. G. Winder, P. J. Brennan \& S. A. Rooney, unpublished observations) and hence its synthesis tends to outrun that of protein when the synthesis of the latter is thus slowed.

A third form of growth limitation appears when the amino acid concentration in the medium drops below a certain critical value, or when amino acids are replaced by ammonium salts. The critical organic nitrogen concentration in the medium varies with circumstances, but lies in the region of 200 to $500 \mathrm{mg}$. N/l. Calculations based on the figures of Antoine \& Tepper ( $1969 b$ ) suggest that a similar range of organic nitrogen concentrations is also critical for Mycobacterium tuberculosis RIRv. When the amino acid concentration is below the critical level, the growth rate is very markedly reduced and high levels of all carbohydrate fractions of the bacteria are reached. It is suggested that at concentrations of amino acids below the critical one the organisms have 
difficulty in abstracting them from the medium, leading to the observed reduction in the intracellular pool of soluble amino compounds and to a reduction in the rate of protein synthesis with consequent carbohydrate accumulation. These conditions operate even when ammonium ions are present in high concentration, leading to a large intracellular soluble nitrogen pool, as can occur in the glycerol + ammonium sulphate medium; in this case it must be assumed that the provision of at least some of the organism's amino acid requirements from ammonium salts and glycerol is a slow process. Bowles \& Segal (1965) have reported that glutamate represses glycerol utilization of $M$. tuberculosis $\mathrm{H} 37 \mathrm{Rv}$, so that de-repression of glycerol utilization might reinforce the tendency of the bacteria to accumulate carbohydrate at low concentrations of amino acids. However, investigations into the uptake of labelled glycerol, asparagine and glutamate in each other's presence do not suggest that this process plays a major role in regulating the carbohydrate:protein ratio (Winder \& Rooney, I970; F. G. Winder, S. A. Rooney, \& P. J. Collins, unpublished observations).

Characterization of the carbohydrates present in the various fractions of $\mathrm{Myco}$ bacterium tuberculosis $\mathrm{BCG}$ grown in glycerol + asparagine + casein hydrolysate medium is reported elsewhere (Winder \& Rooney, I 970). In the present studies, only in the case of the soluble fraction was an attempt made to identify the individual carbohydrates whose concentration changed in response to growth conditions. In this case, trehalose and a glucan were found to be mainly involved. The carbohydrates which were usually measured in the other fractions contained hexose, since the anthrone method responds only slightly to pentose. Antoine \& Tepper (1969a,b) reported that glycogen is the main carbohydrate which accumulates in Mycobacterium phlei and $M$. tuberculosis under their accumulation conditions.

The relative constancy of the RNA: protein ratio in spite of large changes in growth rate is somewhat surprising in view of the fact that in several bacteria it has been found that the amount of RNA (mainly ribosomal RNA) per unit of nitrogen varies approximately linearly with growth rate over a range of conditions (Magasanik, Magasanik \& Neidhardt, 1959; Neidhardt, 1963). However, at lower growth rates bacteria appear to approach a constant minimal RNA:protein ratio (Magasanik et al. 1959; Maaløe \& Kjeldgaard, 1966) and even the maximal growth rate of Mycobacterium tuberculosis is far below the range studied with other organisms, so that presumably its whole range of growth rates can be dealt with by a minimal concentration of ribosomes, though the constancy of this value still requires explanation. In the more rapidly growing $M$. smegmatis, variation in this ratio can be observed (Winder \& O'Hara, 1962; F. G. Winder \& M. P. Coughlan, unpublished observations), even though its maximal growth rate still lies below the rates which have been studied with other bacteria.

On the other hand, mycobacteria appear to have a rather variable DNA:protein ratio. This ratio is generally constant in growing bacteria, although a limited increase can occur during starvation (Neidhardt, 1963; Maaløe \& Kjeldgaard, 1966). In Mycobacterium smegmatis substantial variations in this ratio can occur (Winder \& O'Hara, I962; F. G. Winder \& M.P. Coughlan, unpublished observations), while in $M$. tuberculosis there is clear evidence for an increase in the ratio as the growth rate in a rich medium declines through clump formation.

The maximal RNA:DNA ratio achieved by Mycobacterium tuberculosis BCG is very low at 2:I, compared with $4: \mathrm{I}$ achieved by $M$. smegmatis and the higher values 
reached by other micro-organisms. This is presumably related to its low maximal growth rate. The values reported here for this ratio for BCG are similar to those found for a number of other strains of $M$. tuberculosis (Winder \& Denneny, 1956). Interference by inorganic polyphosphate in their assay probably contributed to the somewhat high value of 5: I reported for $M$. tuberculosis BCG by Tsumita \& Chargaff (1958), while the very high ratios reported by Youmans \& Youmans (I968) for H37 Ra were probably due to interference by arabinose-containing polysaccharides in the orcinol method used for measuring RNA.

We thank Miss Alice Harrison for technical assistance. This work was supported by grants from the United States Public Health Service (AI-07254), Arthur Guinnessl Son and Company (Dublin) Ltd, The National Science Council of Ireland, and Shel, International Petroleum Company Ltd.

\section{REFERENCES}

Antolne, A. D. \& TePper, B. S. (I969a). Environmental control of glycogen and lipid content of Mycobacterium phlei. Journal of General Microbiology 55, 21 7-226.

ANTOINE, A. D. \& TePPER, B. S. (1969b). Environmental control of glycogen and lipid content of Mycobacterium tuberculosis. Journal of Bacteriology roo, 538-54I.

Bowles, J. A. \& Segal, W. (1965). Kinetics of utilization of organic compounds in the growth of Mycobacterium tuberculosis. Journal of Bacteriology 90, 157-163.

Dubois, M., Gilles, K., Hamilton, J. K., Rebers, P. A. \& Smith, F. (I956). Colorimetric method for determination of sugars and related substances. Analytical Chemistry 28, 350-356.

FRETER, R. \& OzAWA, A. (1963). Explanation for limitation of populations of Escherichia coli in broth cultures. Journal of Bacteriology 86, 904-910.

MaAløe, O. \& KJeldgaARD, N. O. (I966). Control of Macromolecular Synthesis. New York: W. A. Benjamin.

Magasanik, B., Magasanik, A. K. \& Neidhardt, F. C. (1959). In Regulation of Cell Metabolism, pp. 334-349. Edited by G. E. W. Wolstenholme and C. M. O'Connor. London: J. and A. Churchill.

Maruyama, Y., ONo, T. \& Sato, T. (1963). Synchronous growth of Mycobacterium smegmatis as induced by cellular crowding. Journal of General and Applied Microbiology 9, 41-47.

MOORE, S. \& STEIN, W. H. (1954). A modified ninhydrin reagent for the photometric determination of amino acids and related compounds. Journal of Biological Chemistry 211, 907-913.

NeIDHARDT, F. C. (1963). Effects of environment on the composition of bacterial cells. Annual Review of Microbiology $\mathbf{1 7}, 6 \mathrm{I}-86$.

Soltys, M. A. (1952). Tubercle Bacillus and Laboratory Methods in Tuberculosis, p. I29. Edinburgh: E. and S. Livingstone.

TEPPER, B. S. (1965). Modification of cellular constituents during growth of Mycobacterium phlei. American Review of Respiratory Diseases 92, 75-82.

Tsumita, T. \& Chargaff, E. (1958). Studies on nucleoproteins. VI. The deoxyribonucleoprotein and the deoxyribonucleic acid of bovine tubercle bacilli (BCG). Biochimica et Biophysica Acta 29, $568-578$.

Winder, F. G., Brennan, P. J. \& McDonnell, I. (1967). Effects of isoniazid on the composition of mycobacteria, with particular reference to carbohydrates and related substances. Biochemical Journal 104, 385-393.

Winder, F. G. \& DENNENy, J. M. (1956). Phosphorus metabolism of mycobacteria: determination of phosphorus compounds in some mycobacteria. Journal of General Microbiology 15, I-18.

Winder, F. G. \& O'HARA, C. (1962). The effects of iron deficiency and of zinc deficiency on the composition of Mycobacterium smegmatis. Biochemical Journal 82, 98-108.

Winder, F. G. \& RoONEY, S. A. (1970). The effects of isoniazid on the carbohydrates of Mycobacterium tuberculosis BCG. Biochemical Journal $117,355-368$.

Youmans, A.S. \& Youmans, G. P. (I968). Ribonucleic acid, deoxyribonucleic acid, and protein content of cells of different ages of Mycobacterium tuberculosis and the relationship to immunogenicity. Journal of Bacteriology 95, 272-279. 